Науковий вісник НЛТУ України

Scientific Bulletin of UNFU

https://nv.nltu.edu.ua

https://doi.org/10.36930/40310305

Article received 14.04.2021 p.

Article accepted 29.04.2021 p.
ISSN 1994-7836 (print)

ISSN 2519-2477 (online)

$@ \bowtie$ Correspondence author

Yu. O. Rumiankov

rumyankovy@ukr.net

UDC 633.872.1:657.371.1

Ю. О. Рум'янков, О. Л. Порохнява, Г. І. Музика, В. М. Грабовий

Начіональний дендрологічний парк "Софіївка" НАН України, м. Умань, Украӥна

\title{
QUERCUS ROBUR L. В ICTOРИЧНИХ НАСАДЖЕННЯХ НАЦІОНАЛЬНОГО ДЕНДРОЛОГІЧНОГО ПАРКУ "СОФІЇВКА" НАН УКРАЇНИ ЗА РІЗНИХ ФІТОЦЕНОТИЧНИХ УМОВ
}

Проаналізовано видову, вікову, морфологічну та просторову структури насаджень Q. robur в історичному масиві "Дубинка" Національного дендрологічного парку "Софіївка" НАН України. Визначено розподіл території масиву "Дубинка" на дві частини, які відрізняються екологічними та фітоценотичними умовами. Аналізуючи вікову структуру насадження Q. robur, встановлено штучне створення та підтримку визначеної частки дерев дуба у структурі нижньої частини масиву "Дубинка" впродовж всієї історії його розвитку як культурфітоценозу. Не виявлено старих вікових дубів на плакорній частині масиву, що свідчить про наявність екологічних умов, які не сприяють деревам-довгожителям. Доведено можливість утримування чистих насаджень $Q$. robur на плакорі лише за умов формування та підтримки штучного ценозу. Встановлено кількісну частку $Q$. robur у видовій структурі нижньої частини деревостану $-12,8$ \%. З'ясовано неспроможність насіннєвого відновлення дуба у структурі деревостану масиву "Дубинка" впродовж всієї історії розвитку ценозу. Визначено дуже слабке самовідновлення $Q$. robur у нижній частині масиву у початковий період розвитку фітоценозу, про що свідчить істотна вікова різниця між першою та другою групами дерев у 130 років. Доведено стійку здатність домінування граба у лісовому ценозі дендропарку впродовж останніх 70 років. Встановлено зменшення інтенсивності доглядових рубань близько 100 років тому та переведення режиму утримання нижньої частини масиву до більш природних тенденцій розвитку фітоценозу. Виявлено, що чотири вікових групи дерев дуба сигналізують про етапи формування насаджень $Q$. robur одночасно на території всього масиву "Дубинка". На початку кожного етапу садівники парку вирубували малоцінні види та ïx підріст, залишаючи окремі екземпляри бажаних у структурі ценозу дерев. У нижній частині схилу доглядовими рубаннями формували деревостан подібний до природних дубово-грабових угруповань, у структурі яких домінують Carpinus betulus L., Acer platanoides L., Q. robur та Fraxinus excelsior L. У плакорній частині формування чистих насаджень Q. robur в історичному плані $є$ пріоритетним напрямом утримання цієї території як паркового культурфітоценозу. Надано рекомендації зі збереження та оптимізації насаджень Q. robur у культурфітоценозах дендропарку "Софіївка" щодо контролю підросту F. excelsior як едифікатора та C. betulus як повноцінної складової другого ярусу в дубово-грабових угрупованнях. Рекомендовано збільшити частку дуба у структурі ценозу нижньої частини масиву замість малоцінних видів та претендентів на домінування, а також штучно підтримувати визначену частку дерев дуба у структурі культурфітоценозу для збереження чистих насаджень $Q$. robur на території плакорної частини.

Ключові слова: видова структура; вікові групи; природне відновлення; штучне походження; домінантний вид; стратегія догляду; оптимізація.

\section{Вступ}

Основою Національного дендрологічного парку "Софіївка" НАН України є культурфітоценози, які було сформовано свого часу з аборигенних рослин. Питання збереження та догляду основних історичних ділянок парку, таких як "Дубинка", залежить від вчасного корегування небажаних змін у структурі фітоценозу. Остан- нім часом виявлено різке погіршення фітосанітарного стану насаджень $Q$. robur, що стало причиною пришвидшеного відмирання дерев на плакорній частині масиву "Дубинка" [18]. Проте на території нижньої частини масиву "Дубинка" ми не виявили патологічних змін у фітосанітарному стані, а також сухих дерев дуба. Враховуючи безпосередньо близьке розташування нижньої

Інформація про авторів:

Рум'янков Юрій Олегович, канд. біол. наук, наук. співробітник, завідувач лабораторії ландшафтного дизайну та проектування відділу дендрології та паркобудівництва. Email: rumyankovy@ukr.net; https://orcid.org/0000-0002-6253-7618

Порохнява Ольга Леонідівна, канд. біол. наук, ст. наук. співробітник, лабораторія ландшафтного дизайну та проектування, відділ дендрології та паркобудівництва. Email: porokhniava@gmail.com; https://orcid.org/0000-0002-9636-9990

Музика Григорій Іванович, канд. біол. наук, завідувач відділу дендрології та паркобудівництва. Email: musika1@ukr.net; https://orcid.org/0000-0002-3389-363Х

Грабовий Володимир Миколайович, канд. біол. наук, заступник директора з наукової роботи. Email: ndp.sofievka@gmail.com; https://orcid.org/0000-0001-7623-1874

Цитування за ДСТУ: Рум'янков Ю. О., Порохнява О. Л., Музика Г. І., Грабовий В. М. Quercus robur L. в історичних насадженнях національного дендрологічного парку "Софіївка" НАН України за різних фітоценотичних умов. Науковий вісник НЛтУ України. 2021, т. 31, № 3. С. 34-40.

Citation APA: Rumiankov, Yu. O., Porokhniava, O. L., Muzyka, H. I., \& Hrabovyi, V. M. (2021). Quercus robur L. in historical planting of the Sofiivka National Dendrological Park of the NAS of Ukraine in different phytocenotic conditions. Scientific Bulletin of UNFU, 31(3), 34-40. https://doi.org/10.36930/40310305 
частини масиву, який відрізняється наявністю в насадженнях зі збагаченим фітоценотичним складом дерев дуба у задовільному фітосанітарному стані, перед нами постало питання визначення факторів збереження якісного стану дерев $Q$. robur, а також виявлення можливості самовідновлення цього виду за альтернативних умов утримання паркового культурфітоценозу.

Об'єкт дослідження - насадження Q. robur Національного дендрологічного парку "Софіївка" НАН України.

Предмет дослідження - фітоценотична структура насаджень плакорної та нижньої частин масиву "Дубинка".

Мета роботи - порівняти структуру насаджень Q. robur плакорної та нижньої частин схилу масиву "Дубинка", які були сформовані за різних фітоценотичних умов, та виявити можливі шляхи збереження та оптимізації насаджень $Q$. robur у паркових фітоценозах.

Для досягнення зазначеної мети визначено такі основні завдання дослідження:

1. Визначити видову, вікову, морфологічну та просторову структури насаджень $Q$. robur плакорної та нижньої частин схилу масиву "Дубинка".

2. Оцінити вплив фітоценотичної структури насаджень на самовідновлення дерев $Q$. robur.

3. Надати рекомендації з оптимізації та збереження насаджень $Q$. robur у паркових ценозах.

Наукова новизна отриманих результатів дослідження: встановлено наявність чотирьох вікових груп дерев Q. robur масиву "Дубинка"; з'ясовано поетапне формування деревостану та підтримку визначеної частки дерев дуба у структурі нижньої та верхньої частин деревного масиву впродовж всієї історії його розвитку як культурфітоценозу; доведено неспроможність самовідновлення $Q$. robur у лісовому ценозі масиву "Дубинка" НДП "Софіївка"; визначено стійку здатність домінування Carpinus betulus L. у нижній частині масиву "Дубинка".

Практична значущість результатів дослідження: визначено стратегію догляду за ділянками верхньої та нижньої частин історичного масиву "Дубинка", яка враховує особливості фітоценотичних умов формування кожної з них; надано рекомендації щодо контролю кількісної структури $C$. betulus i $F$. excelsior масиву "Дубинка" та формування чистих насаджень $Q$. robur у верхній частині масиву.

Аналіз останніх досліджень та публікацій. За останні сто років на території Європи Q. robur відрізняється ослабленою стійкістю до грибкових та ентомологічних захворювань, а також $є$ неконкурентоспроможним у лісових угрупованнях, тому внаслідок зазначених тенденцій піддається пришвидшеному відмиранню [3, 6, 7, 22].

Перші публікації про масове відмирання байрачних порослевих дібров у Харківській і Полтавській губерніях [4] з'явилися у 40-х роках ХІХ століття.

Причиною деградації і масового всихання дібров $\epsilon$ глобальні кліматичні зміни та посилення антропогенного навантаження $[6,9,15,22]$.

Досвід фахівців лісового господарства свідчить про безперспективність природного відновлення дуба в умовах Степу України $[10,19]$.
За несприятливих умов відбувається зміна ходу онтогенезу, періодизація якого може протікати за скороченою програмою [16].

Віковий спектр насаджень деревних рослин зумовлює динаміку структурного різноманіття, визначає здатність до самовідновлення і ступінь стійкості до впливу природних та антропогенних факторів $[1,2,5,8]$.

Природний лісовідновлювальний процес у деревних рослин значною мірою зумовлений природно-кліматичними факторами та конкретними умовами фітоценозу $[3,9,17,20,21]$. Тому порівняльний аналіз структури насаджень $Q$. robur однієї кліматичної зони, але за різних фітоценотичних умов плакорної та нижньої частин масиву "Дубинка" $є$ актуальним.

Матеріали та методи дослідження. У серпні 2020 р. було проведено дослідження просторової, морфологічної та видової структури лісового культурфітоценозу на історичній ділянці "Дубинка" НДП "Софіївка". Для дослідження цього ценозу ми розділили його на дві ділянки, які сформувалися за різних умов догляду. На кожній ділянці виділили по три пробних площі розміром близько $50 \times 50$ м, які містили в своєму складі характерні структурні елементи [14]. Походження та режими догляду історичної ділянки "Дубинка" аналізували за допомогою монографічних і колективних наукових праць авторів: I. А. Косаревський [11]; I. С. Косенко, Г. Ю. Храбан, В. В. Мітін, В. Ф. Гарбуз [12]; А. Л. Липа [13]. Визначення віку дерева виконували підрахунком товщини річних кілець зрізаних сухих дерев дуба, які росли на території масиву "Дубинка".

\section{Результати дослідження та їх обговорення}

Перш ніж аналізувати структуру фітоценозу насадження масиву "Дубинка", потрібно визначити передумови його виникнення та форми утримання впродовж свого розвитку.

В історичному плані деревний масив "Дубинка" був сформований у $1796-1798$ рр. та займає площу близько 12 га. Його територія - це підвищена вододільна частина між долиною річки Кам'янка зі сходу та Грековою балкою зі заходу. Відповідно цей великий масив ділиться на верхню та нижню частини. Верхня - плакор, це найвища вирівняна частина вододілу площею близько 7 га. Нижня частина - це схил 3 нахилом від 8 до $17^{\circ}$, який переходить у балку річки. Окрім цього, на теритоpiї верхньої частини масиву розташована ще одна не менш важлива ділянка, про яку дослідники написали, що "Центральну частину діброви займає велика і дуже мальовнича галявина Дубинка. Формування іiі завершено у 1985 році. Акцентною точкою поляни є 300-річний дуб і група вікових дерев модрини європейської, в яких ховається альтанка східного типу" [12].

На території масиву "Дубинка" до будівництва парку "Софіївка", за даними дослідників, існував давній лісовий масив, який мав іншу назву та невідоме походження: "На схилі до Нижнього ставу до цього часу залишилися поодинокі дуби та ясени древнього Грекового лісу, який раніше простягався від Кам'янки і до Білогрудівського лісу. Ліс був вирізаний давно, та лише залишки рідкісних орхідних - гніздівки звичайної, коручки темно-червоної і барвінка малого та поодинокі сторічні дуби нагадують про давній лісовий масив" [12]. У своєму часописі О. Л. Липа про поодинокі дуби та ясени давнього Грекового лісу взагалі не згадував: 
"До початку облаштування Софіївки це був остепнений схил, позбавлений будь-якої деревної рослинності, на якому паслися стада" [13].

У нашому випадку важлива обопільна згода дослідників на ідеї штучного походження насадження масиву "Дубинка": "3 самого початку будівництва парку ця вся територія була засаджена переважно дубами 3 додаванням таких видів як граб, ясен, клен, липа" $[11,12,13]$. Згодом, як писав О. Л. Липа у 1948 р.: "за 150 років свого розвитку, вціліли лише поодинокі дуби-велетні. Весь простір навколо цих дубів тепер зайнято насадженнями молодшими, що складаються переважно з граба, який знайшов тут кращі умови зростання, ніж дуб.... У міру зниження по схилу до балки та поліпшення гідрологічних умов, дуб поступово змінюється грабом" [13].

Якщо врахувати різні гідрологічні умови на схилах балки та вирівняному плато, стають зрозумілими якісні зміни в насадженнях, які автор порівнював: "вище на плакорі, де панує вже дуб, зімкнутість крон деревного ярусу не буває більше 0,7; середня повнота 0,5-0,6 і підвищується в міру зниження схилу і зміни співвідношення деревних видів в бік граба" [13].

Граб, на відміну від дуба, завдяки поліпшеним гідрологічним умовам нижньої частини масиву, збільшив свою кількісну частку, як писав О. Л. Липа: "утворивши деревостани близькі до природних свіжих широколистяно-грабових лісів" [13]. Про сприятливі екологічні умови росту рослин у нижній частині та відповідно високий якісний стан насаджень дослідник повідомляв: "Продуктивність їх висока і дорівнюе II і навіть I бонітету. І хоча лісорослинні умови тут будуть оптимальними майже для всіх деревних порід, але мабуть, завдяки втручанню людини, граб тут безроздільно панує, утворюючи майже всюди один деревний ярус. Лише дуже рідко, у вигляді незначної домішки, трапляються інші породи: ясен, дуб, клен, груша, липа та інші" [13].

Про природне походження насаджень нижньої частини було також згадано в описі: "Найвища ділянка діброви створена насадженням дуба звичайного пізнього, граба, зрідка липи, ясена, груші, черешні дикої, тому вона за станом і виглядом відрізняється від природної в нижній частині Дубинки" [12]. Описуючи походження деревостану нижньої частини масиву О. Л. Липа вносить деякі уточнення, що "На ділянці названій Дубинкою 3 найстаріших дерев аборигенної флори, що збереглися від епохи заснування парку до наших днів, ростуть поодинокі вікові дуби-велетні, які вражають своїм віком і розмірами. Такі дерева вкраплені в молодші деревостани, що складаються нині переважно з граба. Зараз і за складом лісоутворювальних порід, і за підліском, підростом та покровом здається, що ця грабова діброва $є$ цілком природною. А тим часом точно відомо, що Дубинка створена штучно" [13].

Відповідно, на час опису в 1948 р. склалися такі лісорослинні умови, що сформували переважно чисті насадження дуба на плакорі з домішками таких видів, як ясен, липа, дика груша, черешня або польовий клен. А в міру зниження схилу перевага у співвідношенні видів зміщувалася у бік граба, де старі екземпляри вікових дубів домішувалися епізодично.

Окрім цього, відсутність старих вікових дубів на плакорній частині масиву свідчить про наявність екологічних умов, які не сприяють деревам-довгожителям. Описуючи низьку якість деревостану плакорної части- ни, О. Л. Липа написав: "На плато деревостан Дубинки близький за складом і умовами росту до природних сухих дібров (Д2), таким характерним для Лісостепу України. Продуктивність дубових деревостанів на Дубинці невисока, що прямо залежить від невідповідних для дуба лісорослинних умов цієї ділянки. Панівним $є$ III бонітет, але з віком дубів бонітет погіршується; стовбури в $60-70$ років стають здебільшого кривими, сучкуватими, крони зрідженими, часто однобокими, місцями із засохлих гілок" [13]. Автор однозначно заявив нам про невідповідність лісорослинних умов верхньої частини масиву "Дубинка" для успішного створення високодекоративних паркових насаджень $Q$. robur.

У такому випадку штучне походження чистих насаджень дуба на плакорі стає очевидним, адже описуючи підлісок О. Л. Липа [13] у списку рослин цей вид не вказує: "Підлісок зазвичай добре розвинутий та складається з глоду (Crataegus ucrainica A. Pojark.), жимолості татарської (Lonicera tatarica L.), жостера (Rhamnus cathartica L.), калини-гордовини (Viburnum lanta$n a \mathrm{~L}$.), зрідка трапляється бересклет европейський (Evonymus europaea L.), ближче до узлісся Дубинки терен (Prunus spinosa L.), степовий мигдаль (Amygdalus nana L.), шипшина (Rosa canina L.) та інші". Але в коментарі додає, що "в ярусі підліску, серед чагарників, місцями чимало підросту деревних порід граба, липи, клена польового та дуба, хоча відновлення дуба природнім шляхом йде все ж таки достатньо слабо. Енергійніше за всіх тут відновлюється граб, навіть у плакорних умовах" [13]. Це засвідчує, що наявна висока чистота дубового деревостану на плакорі зумовлена суто антропогенними чинниками. Адже незначну силу природного поновлення дуба дослідники спостерігали навіть у нижній частині схилу масиву "Дубинка", де на їхню думку, лісорослинні умови є оптимальними майже для всіх видів дерев.

Незважаючи на такий різкий контраст гідрологічних умов на схилах балки та на вирівняному плато, інтенсивного відновлення дуба природним шляхом від часу фундації парку до 1948 р. відзначено не було, тоді як енергійне відновлення граба автори описів відзначали на всій території масиву "Дубинка".

За нашими дослідженнями видової структури деревостану нижньої частини насадження "Дубинка", виявлено найбільшу кількість C. betulus - 57,4 \% (рис. 1). Якщо врахувати кількісну перевагу граба у структурі фітоценозу, яку описав О. Л. Липа вже в 1948 р. [13], то можемо відзначити стійку тенденцію до домінування цього виду у лісовому ценозі дендропарку впродовж останніх 70 років. Як відомо, з початком створення насадження "Дубинка" у 1796-1798 рр. ця вся територія була засаджена переважно дубами, та як вище описано, лише 3 додаванням таких видів, як граб, ясен, клен, липа. Ми не знаємо кількісної частки супутніх видів у структурі посадки того часу, але за 150 років існування деревостану відбулась зміна кількісного співвідношення видів у бік граба, яке зберігається і тепер.

У видовій структурі деревостану ми встановили лише 13,8\% Acer platanoides (див. рис. 1). Але, враховуючи високу інтенсивність поширення клена гостролистого (48,2 \% у підрості) та його життєздатність, можемо впевнено очікувати на домінування цього виду у майбутньому. 


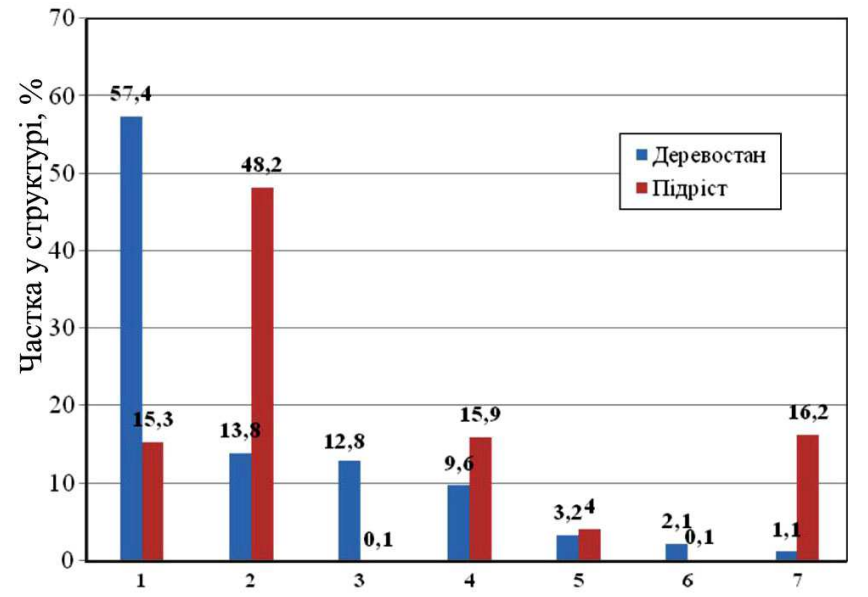

Рис. 1. Видова структура деревостану та підросту нижнього схилу ділянки "Дубинка": 1) Carpinus betulus L.; 2) Acer platanoides L.; 3) Quercus robur L.; 4) Fraxinus excelsior L.; 5) Tilia cordata Mill.; 6) Ulmus laevis Pall.; 7) Acer campestre L.

Кількісна частка C. betulus у підрості становить $15,3 \%$, що в 3 рази менше, ніж у A.platanoides. Вважаємо, що наявний кількісний приорітет граба незабаром може змінитися в бік клена гостролистого, якщо цьому не завадять антропогенні чинники. Таку думку висловив О. Л. Липа, коли припустив, що "мабуть, завдяки втручанню людини, граб тут безроздільно панує" [13].

Наразі у видовій структурі деревостану встановлено лише $12,8 \%$ Q. robur (див. рис. 1). Цей показник дуже близький за значенням до кількості A.platanoides, але такої високої інтенсивності поширення як у клена $Q$. robur не має. За низького показника здатності до самовідновлення дуба (0,1 \% у підрості) не варто очікувати збільшення кількісного показника $Q$. robur у структурі деревостану. Можливо навіть, що домінування $Q$. robur було актуальним лише під час створення масиву та впродовж життя посаджених дерев дуба. Упродовж всього існування нижньої частини деревостану "Дубинка", як за свідченнями дослідників того часу, так і в наших дослідженнях, тенденції до самовідновлення Q. robur відзначено не було.

Кількісна частка $F$. excelsior $(9,6 \%)$ у насадженні наразі нижча за $Q$. robur на $2 \%$ (див. рис. 1). Якщо врахувати, що цей вид було висаджено з самого початку заснування парку, а також його стрімку стратегію поширення та едифікаторну спроможність варто було очікувати на цей час з його боку більшого контролю над територією. Частка $F$. excelsior в структурі підросту $(15,9 \%)$ навіть дещо більша, ніж у C. betulus $(15,3 \%)$, який у структурі деревостану наразі є домінантним. Однаковий кількісний потенціал підростів $F$. excelsior та C. betulus у майбутньому деревостані має всі підстави перейти на домінування ясена. Зворотну ситуацію, яка виникла певно не вперше, ми могли б пояснити лише впливом антропогенного чинника.

У такому випадку, стверджувати, що видовий склад нижнього схилу масиву "Дубинка" сформувався внаслідок природних тенденцій розвитку фітоценозу, ініційованого під час фундації парку, можливо тільки частково. Ймовірніше, що підріст F. excelsior, як потенційного едифікатора, садівники парку періодично видаляли на користь дуба, який з самого початку створення парку мав дуже слабке природне поновлення навіть у нижній частині масиву "Дубинка".
Кількісна частка $T$. cordata у структурі деревостану зовсім невелика (3,2 \%), певно, що від початку створення парку до наших днів цей вид не змінив свого статусу, залишаючись у насадженні у вигляді домішки (див. рис. 1). Кількісна частка липи у підрості (4\%) свідчить також про стабільність свого місця у цьому культурфітоценозі.

У випадку $U$. laevis, якого у структурі насадження зовсім мало (2,1\%), передбачити його перспективу в деревостані досить складно, а 3 показником 0,1 \% у підрості треба визнати цей вид не життєздатним у цьому ценозі.

Найперспективнішим виявився $A$. campestre, якщо врахувати його зовсім малу кількість у деревостані $(1,1 \%)$, але в 15 разів більшу частку у підрості (16,2\%), показником якої він поступається лише Acer platanoides. Як на наш погляд, то в майбутньому існує велика ймовірність виходу $A$. campestre та $A$. platanoides в панівне положення у ценозі нижньої частини масиву "Дубинка".

Вивчаючи морфологічну структуру насадження нижньої частини масиву "Дубинка", ми визначили три вікових групи $Q$. robur, які різняться за величиною діаметра стовбура (таблиця).

Таблиця. Морфологічна структура дерев Q. robur на дослідних ділянках насадження "Дубинка"

\begin{tabular}{|c|c|c|c|}
\hline $\begin{array}{c}\text { Вікова група, } \\
\text { №/Кількість дерев, } \\
\text { шт. }\end{array}$ & $\begin{array}{c}\text { Висота рос- } \\
\text { лини, м }\end{array}$ & $\begin{array}{c}\text { Діаметр } \\
\text { стовбура, см }\end{array}$ & $\begin{array}{c}\text { Діаметр кро- } \\
\text { ни, м }\end{array}$ \\
\hline \multicolumn{4}{|c|}{ Нижня частина масиву } \\
\hline I/1 & 24 & 162 & 14 \\
\hline II/4 & $23^{ \pm 2,0}$ & $90,5^{ \pm 6,5}$ & $14,5^{ \pm 0,5}$ \\
\hline III/7 & $23,1^{ \pm 1,9}$ & $62,6^{ \pm 5,4}$ & $10^{ \pm 2}$ \\
\hline \multicolumn{4}{|c|}{ Плакор } \\
\hline II/11 & $23,23^{ \pm 2,58}$ & $82^{ \pm 15}$ & $10,5^{ \pm 4,4}$ \\
\hline III/39 & $22,21^{ \pm 1,58}$ & $58,8^{ \pm 1,2}$ & $9,5^{ \pm 2,5}$ \\
\hline IV/24 & $19,95^{ \pm 2,85}$ & $42,5^{ \pm 6,5}$ & $8,2^{ \pm 5,7}$ \\
\hline \multicolumn{4}{|c}{ Галявина } \\
\hline I/1 & 30 & 185 & 21,6 \\
\hline
\end{tabular}

До першої групи ввійшло лише одне дерево діаметром 162 см та заввишки 24 м. Річний приріст у діаметрі стовбура дуба на цій території становить в середньому $5,5^{ \pm 2,4}$ мм. Сухостійних дерев дуба в нижній частині схилу виявлено не було, тому ми керувалися у своїх розрахунках розмірами річних кілець зрізаних дерев у плакорній частині насаджень. Вік дерева Q. robur у першій групі становить близько 294 роки, а враховуючи кращі гідрологічні умови нижнього схилу, можливо, дещо менше.

Другу групу формують 4 дерева із практично в 2 рази меншим середнім показником діаметра стовбура $\left(90,5^{ \pm 6,5}\right.$ см), ніж у першій групі. Вік таких деревблизько $164^{ \pm 11,8}$ років. Перша та друга групи дерев різняться між собою істотним віковим проміжком (130 років), що свідчить про дуже слабке насінне поновлення Q. robur у початковий період розвитку фітоценозу або навіть про повну відсутність його самовідновлення. Тому появу другого покоління дуба ініціювали садівники 3 причин втрати належного кількісного складу $Q$. robur у структурі історичного насадження під назвою "Дубинка".

Третю групу формувала вже більша кількість дерев (7 шт.) 3 діаметром стовбура $62,6^{ \pm 5,4}$ см., вік яких стано- 
вить $113^{ \pm 9,8}$ років. Немає підстав стверджувати, що це покоління дерев $\epsilon$ результатом природного поновлення, ймовірніше, що дві останні групи дерев дуба також посадили садівники, як у випадку штучного створення масиву "Дубинка" на початку фундації дендропарку.

Вивчаючи морфологічну структуру насадження плакорної частини масиву "Дубинка", ми також визначили три вікових групи Q. robur. Відмінністю у віковій структурі плакорної частини є наявність у насадженні молодих дерев IV групи та відсутність дерев I групи. Тобто вікових дерев часів створення парку на всій території плакорної частини масиву "Дубинка" не залишилось жодного. Проте існує єдине дерево дуба, яке росте не в загальній масі деревостану, а на галявині, яка територіально належить до плакорної частини (рис. 2). Діаметр стовбура такого дуба 185 см, що за нашими підрахунками відповідає віку 336 рокам. Тобто, незважаючи на недостатній гідрологічний режим та невідповідність для дуба лісорослинних умов цієї ділянки, про що писав О. Л. Липа [13], це дерево залишилось дотепер. Це унікальне дерево заввишки 30 м із широкою кроною, проекція якої 21,6 м (див. таблицю). У його кроні відзначено кілька сухих і зламаних гілки, дупла наразі відсутні. Нижні скелетні гілки, кінці яких було обрізано, колись прикривали стовбур дуба на висоті трьох метрів. Повноцінна широка та розлога крона дерева в недалекому минулому вказує на те, що цей дуб ріс та формувався без участі підгону.

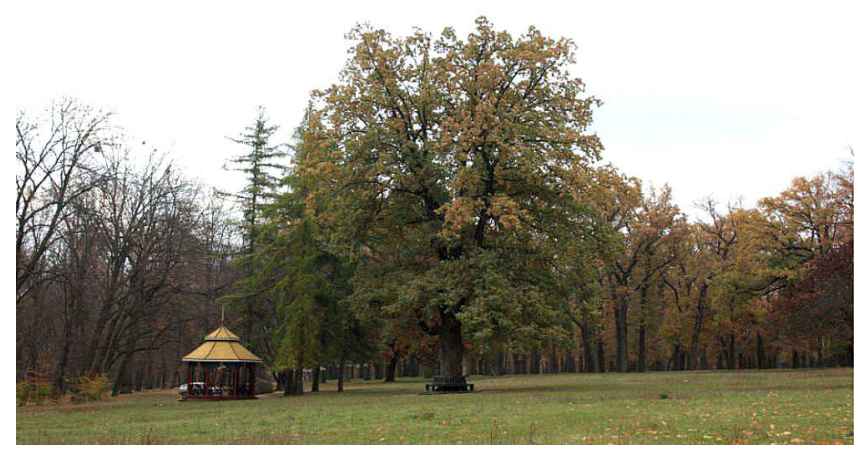

Pис. 2. Q. robur на території галявини "Дубинка" плакорної частини масиву

До другої групи плакорної частини масиву ввійшли дерева дуба 3 діаметром стовбура в середньому $82,0^{ \pm 15,0} \mathrm{~cm}$, віком близько $149^{ \pm 27}$ років. Враховуючи кращі гідрологічні умови нижньої частини масиву, де діаметр стовбура дерев другої вікової групи більший на 8 см, можемо стверджувати, що загалом дерева на плакорі та в нижній частині схилу другої вікової групи були посаджені водночас.

До третьої групи плакорної частини масиву ввійшли дерева дуба віком 107 років з діаметром стовбура в середньому $58,8^{ \pm 11,2}$ см. Цей показник також тільки на 4 см менший, ніж діаметр стовбура у дерев третьої групи нижньої частини масиву. Аналогічну різницю в діаметрі стовбура дерев плакорної та нижньої частин масиву спостерігали у другій віковій групі, що тільки підтверджує думку про одночасну посадку дерев дуба третьої групи в різних частинах масиву.

Кількість дерев у другій віковій групі плакорної частини масиву становить 11 шт., що менше в 4 рази, ніж у третій. Стрімке зменшення кількості дерев у другій гру- пі свідчить про низьку життєвість насадження внаслідок невідповідних культурі дуба екологічних умов на ділянці, що з віком призводить до пришвидшеного випадіння дерев. Утворені у такий спосіб відкриті місця періодично засаджувалися новими саджанцями, що пояснює більшу кількість дерев (39 шт.) у третій віковій групі.

До четвертої групи плакорної частини масиву ввійшли дерева дуба 3 діаметром стовбура в середньому $42,5^{ \pm 6,5}$ см. Це останнє покоління дерев Q. robur, виявлене у плакорній частині масиву, яке за нашими розрахунками було висаджене близько $77^{ \pm 11,8}$ років тому.

Порівнюючи діаметр проєкції крон дерев дуба другої вікової групи плакору та нижньої частини масиву, варто зазначити, що дерева нижньої частини мають на 4 м більший діаметр крони (див. таблицю). Тому зімкнутість крон дуба у нижній частині була меншою, що свідчить про слабкий вплив можливих конкурентних видів під час формування деревостану та відповідно про більш загущені посадки дерев дуба на плакорі.

Дерева дуба третьої вікової групи на плакорі та в нижній частині мають практично однаковий діаметр крони $\left(9,5^{ \pm 2,5}\right.$ та $10^{ \pm 2}$ м відповідно) (див. таблицю). Ми пояснюємо це зменшенням інтенсивності доглядових рубань близько 107 років тому та переведення режиму утримання нижньої частини масиву до природніших тенденцій розвитку культурфітоценозу. Тому четвертої групи дерев дуба в нижній частині виявлено не було, що додатково підтверджує неспроможність природного відновлення $Q$. robur на цій території.

Якщо врахувати малу кількість дерев дуба на плакоpi у другій віковій групі (11 шт.), тоді цілком логічно, що загущені посадки дерев третьої групи (39 шт.) вказують на спробу швидкого відновлення кількісного складу деревостану (див. таблицю). Тому аналогічний прийом збільшення кількості дерев дуба без видалення підросту інших видів (через зміну режиму утримання до природного) у дерев четвертої групи призвів до зменшення діаметра крони $\left(8,2^{ \pm 5,7} \mathrm{M}\right)$.

Наявність чотирьох вікових груп у насадженнях дуба свідчить про штучне походження масиву. Виявлені вікові групи дерев дуба сигналізують етапи формування насаджень одночасно на території всього масиву "Дубинка". На початку кожного етапу садівники парку вирубували малоцінні види та їх підріст, залишаючи окремі екземпляри бажаних в історичному плані видів.

У нижній частині схилу доглядовими рубаннями садівники формували деревостан, подібний до природних дубово-грабових угруповань, у структурі яких домінують $C$. betulus, A. platanoides, $Q$. robur та $F$. excelsior. Якщо з кількістю підросту граба, клена та ясеня нестачі не було, то незначна частка підросту природного відновлення дуба не досягала достатнього рівня у структурі деревостану. Тому для відновлення історичного деревного масиву під назвою "Дубинка", на відкритих місцях після доглядових рубань висаджували саджанці дуба, які сформували другу та третю вікові групи дерев у нижній частині схилу.

Причиною відсутності в насадженнях нижньої частини четвертої вікової групи дерев дуба, на нашу думку, були неспроможність його природного відновлення 
та перехід режиму догляду на природні тенденції розвитку фітоценозу.

Плакорній частині масиву "Дубинка", зважаючи на історичне значення та зручність механізованого догляду, садівники парку приділяли найбільше уваги. Періодично викошували трав'яний покрив, вирізували підріст інших видів, підсаджуючи саджанці дуба, створювали чисті монокультурні насадження $Q$. robur, що було пріоритетом утримання цієї території як паркового культурфітоценозу.

\section{Висновки}

1. За результатами нашого дослідження видової структури деревостану нижньої частини насадження "Дубинка" виявлено найбільшу кількість C. betulus $57,4 \%$, а також визначено стійку здатність домінування цього виду у лісовому ценозі впродовж останніх 70 років. Встановлено, що кількісний показник $Q$. robur y деревостані становить 12,8 \%, що свідчить про втрачений статус домінування з часу формування історичного масиву "Дубинка". Доведено неспроможність самовідновлення Q. robur у лісовому ценозі масиву "Дубинка" НДП "Софіївка".

2. Встановлено наявність чотирьох вікових груп дерев $Q$. robur масиву "Дубинка". Відмінністю у віковій структурі плакорної частини масиву $є$ наявність у насадженні молодих дерев дуба IV групи та відсутність вікових дерев I групи. Найстарше дерево дуба I групи віком 336 роки виявлене на плакорній частині масиву. Дерева $Q$. robur IV вікової групи у плакорній частині масиву були висаджені близько $77^{ \pm 11,8}$ років тому. Визначені вікові групи дерев дуба сигналізують етапи формування насаджень одночасно на території всього масиву "Дубинка".

3. Аналізуючи просторову структуру нижньої частини масиву "Дубинка", встановлено формування більш повноцінної форми крони у дерев дуба (діаметр крони $14,5^{ \pm 0,5}$ м) при кількісному співвідношенні 4 дерева на $2500 \mathrm{~m}^{2}$ площі. Збільшення кількості дерев дуба (до 74 шт.) на плакорній частині масиву призвело до зменшення діаметра крони $\left(8,2^{ \pm 5,7} \mathrm{M}\right)$.

4. Аналізуючи морфологічну структуру дерев на дослідних ділянках, встановлено, що найвище дерево дуба заввишки 30 м та діаметром стовбура 185 см росте солітерно на галявині плакорної частини. Найвище дерево в нижній частині масиву, яке було сформоване в умовах дубово-грабового угруповання - заввишки 24 м та діаметром стовбура 162 см. Найнижчі дерева заввишки $19,9^{ \pm 2,8}$ м та діаметром стовбура $42,5^{ \pm 6,5}$ см відзначено на плакорній частині масиву.

5. Для оптимізації та збереження насаджень $Q$. robur у культурфітоценозах дендропарку "Софіївка" рекомендуємо контролювати доглядовими рубаннями підріст $F$. excelsior як потенційного едифікатора та конкурента дуба, а також підтримку його кількісного показника в деревостані на рівні 10 \%. Використовуючи стійку тенденцію домінування C. betulus, варто утримувати кількісну частку граба у лісовому ценозі нижньої частини масиву "Дубинка" на рівні 60 \% як повноцінну складову другого ярусу в дубово-грабових угрупованнях. Рекомендовано збільшити частку дуба у структурі ценозу нижньої частини масиву внаслідок видалення малоцінних видів та претендентів на домінування. Обов'язко- вою умовою збереження чистих насаджень Q. robur у верхній частині деревостану є штучна підтримка визначеної кількості дерев дуба у структурі культурфітоценозу.

\section{References}

1. Alekseev, A. S. (2003). Monitoring lesnykh ekosistem. (2nd ed. add. and revised). St. Petersburg: LTA. [In Russian].

2. Alekseev, V. A. (1989). Diagnostika zhiznennogo sostoianiia derevev i drevostoev. Lesovedenie, 4, 51-57. [In Russian].

3. Alentev, P. N. (1990). Problemy vosstanovleniia i vyrashchivaniia dubrav. Maykop. [In Russian].

4. Borodaevskii, L. S. (1909). Usykhanie lesa v Maiatckoi dache Maiatckogo lesnichestva Kharkovskoi gubernii. Lesnoy zhurnal, 6, 688-711. [In Russian].

5. Iarmishko, V, T., Gorshkov, V. V., \& Stavrova, N. I. (2003). Vitalitetnaia struktura Pinus sylvestris L. V lesnykh soobshhestvakh s raznoi stepeniu i tipom antropogennoi narushennosti (Kolskii poluostrov). Rastitelnye resursy, 39(4), 1-20. [In Russian].

6. Kalinichenko, N. P. (2000). Dubravy Rossii. Moscow: VNIITSlesresurs. [In Russian].

7. Kalinichenko, N. P., \& Novoseltcev, V. D. (1990). Problemy ustoichivosti i produktivnosti dubrav SSSR. Upr. lesami i sovremen. dostizheniia les. nauki v SSSR, 145-154. [In Russian].

8. Karpechenko, K. A., Karpechenko, I. Iu., Zemlianukhina, O. A., Veprintcev, V. N., Kondrateva, A. M., Karpechenko, N. A., \& Kalaev, V. N. (2013). Izuchenie metabolizma pliusovykh derevev duba chereshchatogo (Quercus robur L.) Fundamentalnye issledovaniia, 1, 287-291. [In Russian].

9. Kelly, P. M., Munro, M. A. R., Hughes, M. K., \& Goodness, S. M. (1989). Climate and signature years in west European oaks. Nature, 340, 57-60.

10. Kharchenko, N. A. (2012). K voprosu o estestvennom vozobnovlenii duba chereshchatogo pod pologim materinskim drevostoem. Scientific journal KubGAU, 76, 1-13. [In Russian].

11. Kosarevskiy, I. A. (1951). Gosudarstvennyy zapovednik "Sofiev$k a$ ". Kiev: Izd-vo Akademii arkhitektury USSR. [In Russian].

12. Kosenko, I. S., Khraban, H. Yu., Mitin, V. V., \& Harbuz, V. F. (1996). Dendrolohichnyy park "Sofiivka". Kyiv: Naukova dumka. [In Ukrainian].

13. Lipa, A. L. (1948). Sofievka Umanskiy gosudarstvennyy zapovednik (1796-1946). Kiev: Izd-vo AN USSR.

14. Mirkin, B. M., \& Rozenberg, G. S. (1978). Fitotcenologiia: Printcipy i metody. Moscow: Science, 268 p. [In Russian].

15. Polozhentcev, P. A. (1980). K etiologii otmiraniia dubrav. Prichiny usykhaniia dubrav Moldavii: Sb. statei., 143-151. [In Russian].

16. Rabotnov, T. A. (1950). Zhiznennye tcikly mnogoletnikh travianistykh rastenii v lugovykh tcenozakh. Proceedings of the Botanical Institute AN SSSR, 3(6), 201-204. [In Russian].

17. Rozhkov, A. A., \& Kozak, V. T. (1984). Ustoichivost lesov. Moscow: Agropromizdat. [In Russian].

18. Rumiankov, Y. O. (2019). Pryskorene vidmyrannia duba chereshchatoho (Quercus robur L.) u parkovomu fitotsenozi dilianky "Dubynka" Natsionalnoho dendrolohichnoho parku "Sofiivka" NAN Ukrainy. Journal of Native and Alien Plant Studies, 15, 125-132. https://doi.org/10.37555/.15.2019.184913

19. Semerikov, L. F. (1986). Populiatcionnaia struktura drevesnykh rastenii (na primere vidov duba Evropeiskoi chasti SSSR i Kavkaza). Moscow: Science. [In Russian].

20. Slepykh, A. A., \& Korshykov, Y. Y. (2015). Yzmenchyvost duba chereshchatoho (Quercus robur L.) po fenotypycheskym pryznakam lystev v Stepnoi zone Ukrayny. Bulletin of the Odessa National University. Biology, 20(2), 30-41. [In Ukrainian].

21. Viscosi, V., Lepais, O., Gerber, S., \& Fortini, P. (2009). Leaf morphological analyses in four European oak species (Quercus) and their hybrids: A comparison of traditional and geometric morphometric methods. Plant Biosystems, 143(3), 564-574.

22. Vorontcov, A. I. (1978). Patologiia lesa. Moscow: Lesn. prom-t. [In Russian]. 


\section{QUERCUS ROBUR L. IN HISTORICAL PLANTING OF THE SOFIIVKA NATIONAL DENDROLOGI- CAL PARK OF THE NAS OF UKRAINE IN DIFFERENT PHYTOCENOTIC CONDITIONS}

The sharp deterioration of the phytosanitary status of $Q$. robur planting caused the accelerated extinction of tress on the upper part of Dubinka forest stand. Therefore, the aim of the study is to compare the species composition and age structure of $Q$. robur planting on the upper and lower parts of Dubinka forest stand, which were formed in different phytocenotic conditions, and also identify possible ways to preserve and optimize of oak planting in park phytocenoses. Studying the structure of the phytocenosis, we selected three trial plots in each part of the forest stand with a size of about $50 \times 50 \mathrm{~m}$, which contained characteristic elements. We analyzed the origin and maintenance mode of the Dubinka historical forest stand based on monographic and collective scientific works of A.l. Lipa, S.S. Kosenko, H. Yu. Khraban, V.V. Mitin, V.F. Harbuz, and I.A. Kosarevskiy. The presence of four age groups in the $Q$. robur planting indicates the artificial origin of the Dubinka forest stand. The identified age groups of oak trees signal the stages of simultaneous formation of $Q$. robur planting on the territory of the whole Dubinka forest stand. At the beginning of each stage, low-value species and their undergrowth were cut down, leaving individual specimens of trees desirable in the structure. In the lower part, a forest stand similar to natural oak-hornbeam groups was formed, the structure of which is dominated by $C$. betulus, $A$. platanoides, $Q$. robur and $F$. excelsior. The formation of pure oak planting of the upper part of the forest stand in historical terms is a priority for the maintenance of this territory as a cultural phytocenosis. The absence in the planting of the lower part of the fourth age group of oak trees confirms the failure of natural recovery of $Q$. robur and the cancellation of measures to maintain the historical context of the Dubinka forest stand, - the corresponding planting of young oak trees about 100 years ago. For optimization and preservation of $Q$. robur planting in cultural phytocenoses of the Sofiivka Dendrological Park, we recommend controlling the undergrowth of $F$. excelsior by felling as a potential edificator and competitor of oak and maintaining its number in the forest stand at $10 \%$. Using the steady tendency of $C$. betulus to dominate, the quantitative share of hornbeam in the forest coenosis of the lower part of the Dubinka forest stand should be kept at the level of $60 \%$ as a full-fledged component of the second tier in oak-hornbeam communities. We recommend increasing the share of oak in the structure of the lower part of the forest stand due to low-value and dominant species. Given the low degree of self-healing, a prerequisite for the preservation of clean of Q. robur planting in the upper part of the forest stand is the artificial maintenance of a certain number of oak trees in the structure of the phytocenosis.

Keywords: species structure; age groups; natural recovery; artificial origin; dominant species; care strategy; optimization. 